$\begin{array}{ll}\text { Abstracta Iranica } & \begin{array}{l}\text { Abstracta Iranica } \\ \text { Revue bibliographique pour le domaine irano-aryen }\end{array} \\ & \text { Volume } \mathbf{2 8} \mid \mathbf{2 0 0 7} \\ & \text { Comptes rendus des publications de } \mathbf{2 0 0 5}\end{array}$

\title{
Persica. Volume 20, 2004-2005, Louvain, Peeters, 150 p.
}

Rédaction

\section{OpenEdition}

1 Journals

Édition électronique

URL : http://journals.openedition.org/abstractairanica/9532

DOI : 10.4000/abstractairanica.9532

ISSN : 1961-960X

Éditeur :

CNRS (UMR 7528 Mondes iraniens et indiens), Éditions de l'IFRI

\section{Édition imprimée}

Date de publication : 15 mai 2007

ISSN : 0240-8910

\section{Référence électronique}

Rédaction, « Persica. Volume 20, 2004-2005, Louvain, Peeters, 150 p. », Abstracta Iranica [En ligne], Volume 28 | 2007, document 14, mis en ligne le 18 septembre 2007, consulté le 25 septembre 2020. URL : http://journals.openedition.org/abstractairanica/9532 ; DOI : https://doi.org/10.4000/ abstractairanica.9532

Ce document a été généré automatiquement le 25 septembre 2020.

Tous droits réservés 


\section{Persica. Volume 20, 2004-2005, Louvain, Peeters, 150 p.}

\section{Rédaction}

Jos Biegstraaten, «Omar with a Smile Parodies in Books on FitzGerald's Rubáiyát of Omar Khayyám», pp. 1-37; Teresa Kirk, « The Edinburgh al-Biruni Manuscript A Holistic Study of its Design and Images », pp. 39-81; Bernd Radtke, "Eine alte FrageWoher stammt die islamische Mystik? », pp. 83-89; Leo Jungeon Oh, « Islamicised pseudo-Buddhist Iconography in Ilkhanid Royal Manuscripts », pp. 91-154 ; Riccardo Zipoli, «Semiotics and the Tradition of the Image », pp. 155-172.

INDEX

Thèmes : 1.2. Recueils d'articles : revues, colloques, ouvrages collectifs

\section{AUTEURS}

\section{RÉDACTION}

Directeur de la revue et secrétariats (Paris et Téhéran) 